\title{
Model Pembelajaran Problem Based Learnig (PBL) di Kelas Rendah pada Matematika
}

\author{
Nur Idayani Sugesti \\ SD Negeri Songgom 01 \\ nuridaysugesti@gmail.com
}

\section{Article History}

received 3/12/2020

\begin{abstract}
One of the objectives of teaching and learning activities is to improve learning outcomes or student achievement. For this reason, it is very necessary for a teacher to do various ways so that these goals are achieved, including by applying various kinds of learning models that can increase the activeness of students in learning activities in the hope that this will also have an impact on improving student learning outcomes. How to increase the activity of students in low grades is a challenge for teachers because they see their relatively low cognitive development as well as the nature of boredom that is often faced by students in learning activities. An example of a learning model that can be applied to increase the activity of students in low grades in particular is by using the Problem Based Learning (PBL) learning model. With the application of this PBL learning model, students individually and in groups will use various thinking skills to solve problems, especially in learning activities.
\end{abstract}

Keywords: student activity, low class, learning outcomes, Problem Based Learning (PBL)

\begin{abstract}
Abstrak
Salah satu tujuan kegiatan belajar mengajar adalah untuk meningkatkan hasil belajar atau prestasi peserta didik. Untuk itu sangat perlu kiranya bagi seorang guru melakukan berbagai cara agar tujuan tersebut tercapai, diantaranya dengan menerapkan berbagai macam model pembelajaran yang bisa meningkatkan keaktifan peserta didik dalam kegiatan pembelajaran dengan harapan hal ini akan berdampak pula pada peningkatan hasil belajar peserta didik. Bagaimana cara meningkatkan keaktifan peserta didik di kelas rendah merupakan tantangan tersendiri bagi guru karena melihat perkembangan kognitif mereka yang masih relatif rendah juga sifat rasa cepat bosan yang sering dihadapi oleh peserta didik dalam kegiatan pembelajaran. Contoh model pembelajaran yang bisa diterapkan untuk meningkatkan keaktifan peserta didik di kelas rendah khususnya yaitu dengan menggunakan model pembelajaran Problem Based Learning (PBL). Dengan penerapan model pembelajaran PBL ini peserta didik secara individu maupun kelompok akan menggunakan berbagai kemampuan berpikir untuk mengatasi masalah khusunya dalam kegiatan pembelajaran.
\end{abstract}

Kata kunci: peserta didik, kelas rendah, hasil belajar, Problem Based Learning (PBL)

Social, Humanities, and Education Studies (SHEs): Conference Series https://jurnal.uns.ac.id/shes 


\section{PENDAHULUAN}

Guru sebagai pendidik pada jenjang satuan pendidikan usia dini, dasar, dan menegah memiliki peran yang sangat penting dalam menentukan keberhasilan peserta didik sehingga menjadi determinan peningkatan kualitas pendidikan di sekolah. Pentingnya peran guru dalam pendidikan diamatkan dalam Undang-Undang Republik Indonesia Nomor 20 Tahun 2003 tentang Sistem Pendidikan Nasional pada pasal 3 yang berbunyi: "Pendidikan nasional berfungsi mengembangkan kemampuan dan membentuk watak serta peradaban bangsa yang bermartabat dalam rangka mencerdaskan kehidupan bangsa, bertujuan untuk berkembangnya potensi peserta didik agar menjadi manusia yang beriman dan bertakwa kepada Tuhan Yang Maha Esa, berakhlak mulia, sehat, berilmu, cakap, kreatif, mandiri, dan menjadi warga negara yang demokratis serta bertanggung jawab." Dari situ sudah jelas fungsi guru dalam mengembangkan kemampuan peserta didik dalam meningkatkan kualitas Pendidikan di Indonesia.

Proses pembelajaran yang baik harus disesuaikan dengan karakteristik peserta didik agar peserta didik dapat menangkap materi yang diajarkan dengan baik. Pembelajaran yang dilakukan oleh guru juga harus kreatif dan tidak boleh monoton sehingga peserta didik tidak bosan. Penyampaian materi juga harus bervariasi agar peserta didik terdorong semangatnya sehingga aktif dan terus belajar. Guru tidak hanya berfokus pada penyampaian materinya tetapi juga harus memperhatikan perkembangan peserta didik yang terjadi di dalam proses pembelajaran.

Menurut Brunner dalam Sugandi (2007:36) ada empat hal pokok penting yang perlu diperhatikan yaitu peranan pengalaman struktur pengetahuan, kesiapan mempelajari sesuatu, intuisi dan cara membangkitkan motivasi belajar. Guru dituntut untuk bisa membawa peserta didik ke dalam dunia yang menyenangkan di dalam pembelajaran. Peserta didik yang merasa nyaman dan senang, maka akan berani untuk aktif dan akan mempunyai motivasi lebih untuk terus belajar. Peserta didik yang mempunyai motviasi lebih untuk belajar biasanya akan mendapatkan hasil belajar yang baik. Guru sebagai pemegang proses pembelajaran harus bisa menyajikan hal terbaik. Model pembelajaran yang digunakan haruslah sesuai dengan materi yang sedang diajarkan, karena tidak semua model pembelajaran dapat digunakan untuk semua materi. Pemilihan model pembelajaran akan mendukung hasil pembelajaran yang akan dicapai. Semua muatan pelajaran membutuhkan penerapan model pembelajaran.

Salah satu muatan pelajaran yang menuntut penggunaan model pembelajaran yang sesuai di kelas rendah adalah muatan pelajaran Matematika. Secara bahasa (lughowi), kata "Matematika" berasal dari bahasa Yunani yaitu "Mathema" atau mungkin juga "Mathematikos" yang artinya hal-hal yang dipelajari. Matematika suatu alat untuk mengembangkan cara berfikir. Matematika secara umum didefinisikan sebagai bidang ilmu yang mempelajari pola dari struktur, perubahan dan ruang. Maka secara informal dapat juga di sebut sebagai ilmu bilangan dan angka. Dalam pandangan formalis, matematika adalah penelaahan struktur abstrak yang didefinisikan secara aksioma dengan menggunakan logika simbolik dan notasi. Adapun pandangan lain bahwa matematika adalah ilmu dasar yang mendasari ilmu pengetahuan lain. Menurut W.W Sawyer berpendapat bahwa matematika adalah klasifikasi studi dari semua kemungkinan pola. Pola yang dimaksud disini adalah dalam arti luas, mencakup hampir semua jenis keteraturan yang dapat dimengerti pikiran kita. Setiap teori matematika harus memperhitungkan kekuatan matematika, yaitu aplikasinya terhadap ilmu lain sains yang utama dan keindahan matematika. Terlihat disini matematika bukanlah ilmu yang hanya untuk keperluan dirinya sendiri, tetapi ilmu yang bermanfaat sebagian besar ilmuilmu yang lain.

Untuk itu perlu kiranya guru menerapkan model pembelajaran yang tepat agar tujuan pembelajaran bisa tercapai secara maksimal khususnya untuk muatan pelajaran Matematika sedini mungkin di kelas rendah. Menurut Sujana (2009: 3) hasil belajar 
peserta didik pada hakekatnya adalah perubahan tingkah laku. Tingkah laku sebagai hasil belajar dalam pengertian yang luas mencakup bidang kognitif, afektif dan psikomotoris. Selain perubahan tingkah laku, jika di sekolah hasil belajar biasanya dinilai dengan angka. Peserta didik akan mendapat nilai yang akan menggambarkan keberhasilan dalam belajar. Penerapan model pembelajaran Problem Based Learning (PBL) diharapkan akan dapat membantu peningkatan hasil belajar muatan pelajaran Matematika di kelas rendah.

\section{HASIL DAN PEMBAHASAN}

Kurikulum 2013 menurut Permendikbud Nomor 22 Tahun 2016 tentang Standar Proses menggunakan 3 (tiga) model pembelajaran yang diharapkan dapat membentuk perilaku saintifik, social serta mengembangkan rasa keingintahuan. Ketiga model tersebut adalah: (1) model Pembelajaran Melalui Penyingkapan/Penemuan (Discovery/Inquiry Learning), (2) model Pembelajaran Berbasis Masalah (Problembased Learning/PBL), (3) model Pembelajaran Berbasis Proyek (Project-based Learning/PJBL). Selain 3 model yang tercantum dalam Permendikbud Nomor 22 Tahun 2016, guru juga diperbolehkan untuk mengembangkan pembelajaran di kelas dengan menggunakan model pembelajaran yang lain, seperti Cooperative Learning yang mempunyai berbagai metode seperti: Jigsaw, Number Head Together (NHT), Make a Match, Think-Pair-Share (TPS), Example, Picture and Picture, dan lainnya.

Model pembelajaran berbasis masalah merupakan pembelajaran yang menggunakan berbagai kemampuan berpikir dari peserta didik secara individu maupun kelompok serta lingkungan nyata untuk mengatasi permasalahan sehingga bermakna, relevan, dan kontekstual (Tan Onn Seng, 2000)

Tujuan PBL adalah untuk meningkatkan kemampuan dalam menerapkan konsepkonsep pada permasalahan baru/nyata, pengintegrasian konsep Higher Order Thinking Skills (HOTS), keinginan dalam belajar, mengarahkan belajar diri sendiri, dan keterampilan (Norman and Schmidt).

Karakteristik yang tercakup dalam PBL menurut Tan (dalam Amir, 2009) antara lain: (1) masalah digunakan sebagai awal pembelajaran; (2) biasanya masalah yang digunakan merupakan masalah dunia nyata yang disajikan secara mengambang (illstructured); (3) masalah biasanya menuntut perspektif majemuk (multiple-perspective); (4) masalah membuat pembelajar tertantang untuk mendapatkan pembelajaran di ranah pembelajaran yang baru; (5) sangat mengutamakan belajar mandiri; (6) memanfaatkan sumber pengetahuan yang bervariasi, tidak dari satu sumber saja, dan (7) pembelajarannya kolaboratif, komunikatif dan kooperatif. Karakteristik ini menuntut peserta didik untuk dapat menggunakan kemampuan berpikir tingkat tinggi, terutama kemampuan pemecahan masalah.

Pada PBL guru berperan sebagai guide on the side dari pada sage on the stage. Hal ini menegaskan pentingnya bantuan belajar pada tahap awal pembelajaran. Peserta didik mengidentifikasi apa yang mereka ketahui maupun yang belum berdasarkan informasi dari buku teks atau sumber informasi lainnya.

Sintak model Problem-based Learning menurut Arends (2012) sebagai berikut:

a. Orientasi peserta didik pada masalah

b. Mengorganisasikan peserta didik untuk belajar

c. Membimbing penyelidikan individu maupun kelompok

d. Mengembangkan dan menyajikan hasil karya

e. Menganalisis dan mengevaluasi proses pemecahan masalah

Berdasarkan sintaks tersebut, langkah-langkah pembelajaran berbasis masalah yang bisa dirancang oleh guru adalah sebagai berikut: 
SHEs: Conference Series 3 (4) (2020) $715-719$

Tabel1. Langkah-langkah Problem Based Learning

\begin{tabular}{|c|c|c|}
\hline $\begin{array}{c}\text { Langkah } \\
\text { Kerja }\end{array}$ & Aktivitas Guru & Aktivitas Siswa \\
\hline $\begin{array}{l}\text { Orientasi } \\
\text { peserta didik } \\
\text { pada masalah }\end{array}$ & $\begin{array}{l}\text { Guru menyampaikan masalah } \\
\text { yang akan dipecahkan secara } \\
\text { kelompok. Masalah yang } \\
\text { diangkatr hendaknya } \\
\text { kontekstual. Masalah bisa } \\
\text { ditemukan sendiri oleh peserta } \\
\text { didik melalui bahan bacaan } \\
\text { atau lembar kegiatan. }\end{array}$ & $\begin{array}{l}\text { Kelompok mengamati dan } \\
\text { memahami masalah yang } \\
\text { disampaikan guru atau yang } \\
\text { diperoleh dari bahan bacaan yang } \\
\text { disarankan. }\end{array}$ \\
\hline $\begin{array}{l}\text { Mengorganisa } \\
\text { sikan peserta } \\
\text { didik untuk } \\
\text { belajar }\end{array}$ & $\begin{array}{ll}\text { Guru memastikan setiap } \\
\text { anggota memahami tugas } \\
\text { masing-masing. }\end{array}$ & $\begin{array}{l}\text { Peserta didik berdiskusi dan } \\
\text { membagi tugas untuk mencari } \\
\text { data/bahan-bahan/alat yang } \\
\text { diperlukan untuk menyelesaikan } \\
\text { masalah. }\end{array}$ \\
\hline $\begin{array}{l}\text { Membimbing } \\
\text { penyelidikan } \\
\text { individu } \\
\text { maupun } \\
\text { kelompok }\end{array}$ & $\begin{array}{lr}\text { Guru memantau keterlibatan } \\
\text { peserta didik dalam } \\
\text { pengumpulan data/bahan } \\
\text { selama proses penyelidikan }\end{array}$ & $\begin{array}{lr}\begin{array}{l}\text { Peserta didik } \\
\text { penyelidikan }\end{array} & \text { (mencakan } \\
\text { data/referensi/sumber) } & \text { untuk } \\
\text { bahan diskusi kelompok. } & \end{array}$ \\
\hline $\begin{array}{l}\text { Mengembang } \\
\text { kan dan } \\
\text { menyajikan } \\
\text { hasil karya }\end{array}$ & $\begin{array}{l}\text { Guru memantau diskusi dan } \\
\text { membimbing pembuatan } \\
\text { laporan sehingga karya setiap } \\
\text { kelompok siap untuk } \\
\text { dipresentasikan }\end{array}$ & $\begin{array}{l}\text { Kelompok melakukan diskusi } \\
\text { untuk menghasilkan solusi } \\
\text { pemecahan masalah dan hasilnya } \\
\text { dipresentasikan/disajikan dalam } \\
\text { bentuk karya. }\end{array}$ \\
\hline $\begin{array}{l}\text { Menganalisis } \\
\text { dan } \\
\text { mengevaluasi } \\
\text { proses } \\
\text { pemecahan } \\
\text { masalah }\end{array}$ & $\begin{array}{l}\text { Guru membimbing presentasi } \\
\text { dan mendorong kelompok } \\
\text { memberikan penghargaan } \\
\text { serta masukan kepada } \\
\text { kelompok lain. Guru bersama } \\
\text { peserta didik menyimpulkan } \\
\text { materi. }\end{array}$ & $\begin{array}{l}\text { Setiap kelompok melakukan } \\
\text { presentasi, kelompok yang lain } \\
\text { memberikan apresiasi. Kegiatan } \\
\text { dilanjutkan dengan merangkum/ } \\
\text { membuat kesimpulan sesuai } \\
\text { dengan masukan yang diperoleh } \\
\text { dari kelompok lain. }\end{array}$ \\
\hline
\end{tabular}

Penerapan model pembelajaran Problem Based Learnig (PBL) di kelas rendah khususnya pada muatan pelajaran Matematika diharapkan akan mencapai tujuan pembejaran secara maksimal. Dengan menggunakan sintak PBL yang berurutan dan sesuai akan menggugah minat belajar peserta didik untuk berpikir ke tingkat yang lebih tinggi dan peserta didik akan lebih aktif dalam kegiatan belajar karena pembelajaran berpusat pada peserta didik.

Kelebihan model ini menurut Akinoglu \& Tandogan [2] antara lain:

a. Pembelajaran berpusat pada peserta didik;

b. Mengembangkan pengendalian diri peserta didik;

c. Memungkinkan peserta didik mempelajari peristiwa secara multidimensi dan mendalam;

d. Mengembangkan keterampilan pemecahan masalah;

e. Mendorong peserta didik mempelajari materi dan konsep baru ketika memecahkan masalah

f. Mengembangkan kemampuan sosial dan keterampilan berkomunikasi yang memungkinkan mereka belajar dan bekerja dalam tim;

g. Mengembangkan keterampilan berpikir ilmiah tingkat tinggi/kritis; 
h. Mengintegrasikan teori dan praktek yang memungkinkan peserta didik menggabungkan pengetahuan lama dengan pengetahuan baru;

i. Memotivasi pembelajaran;

j. $\quad$ Peserta didik memeroleh keterampilan mengelola waktu;

k. Pembelajaran membantu cara peserta didik untuk belajar sepanjang hayat.

\section{SIMPULAN}

Berdasarkan uraian di atas diharapkan tidak akan ada lagi hambatan yang dialami oleh peserta didik di kelas rendah khususnya untuk meningkatkan hasil belajar secara maksimal. Muatan pelajaran Matematika juga bukan lagi menjadi momok yang menakutkan untuk dipelajari oleh peserta didik. Karena dengan penerapan model pembelajaran yang sesuai ternyata mampu meningkatkan minat dan katifitas peserta didik dalam kegiatan pembelajaran.

Oleh karena itu, sebagai seorang guru memiliki peran penting dalam menyiapkan perangkat pembelajaran yang tepat sebelum mengajar, sehingga peserta didik akan mendapatkan hasil belajar belajar/prestasi sesuai dengan yang diinginkan.

\section{DAFTAR PUSTAKA}

Akinoglu, O.,\& Tandogan, O.R, 2006. The Effect of Problem Based Learning in Science Education Student's Academic Achievement, Attitude and Concept Learning. Eurasia Journal of Mathematics, Science \&Technology Education, 3 (1): 71-81.

Amir, T.M, 2009. Inovasi Pendidikan melalui Problem Based Learning: Bagaimana Pendidik Memberdayakan Pembelajar di Era Pengetahuan. Jakarta: Kencana Prenada Media Group.

Hariwijaya, Meningkatkan Kecerdasan Matematika, (Yogyakarta: Tugupubliser, 2009), hal. 29

Herman Hudojo, Mengajar Matematika, (Jakarta: Delia Press, 1988), hal.74

Lewis, A., \& Smith, D. 1993. Defining High Order Thinking. Theory into Practice, 32 (3): 131-137.

Sudjana, N. 2009. Penilaian Hasil Proses Belajar Mengajar (Cetakan Ketigabelas). Bandung: PT Remaja Rosdakarya.

Sugandi, A. 2007. Teori Pembelajaran. Semarang: UNNES Press. 